\title{
COMMENT
}

\section{LEGISLATION AND RISK OF LOSS CASES}

\author{
ROBERT DILLER*
}

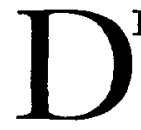
ISCUSSION of the risk of loss under a contract to sell land has in recent years been concerned mainly with the effect of pos-

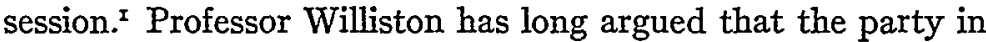
possession should bear the loss, ${ }^{2}$ and he has recently embodied his proposition in a Uniform Vendor and Purchaser Risk Act. ${ }^{3}$ With some changes and additions this act has been adopted in New York. ${ }^{4}$ The legislatures of other states will no doubt be asked to follow suit. In this situation a fresh consideration of the cases may aid in the formation of sound opinion on the desirability of the proposed legislation.

Risk of loss cases raise the question whether a real estate contract should be enforced when the property is destroyed or impaired, without the fault of either party, ${ }^{5}$ during the interval between contract and deed, and where the contract does not provide expressly for such a contingency. ${ }^{6}$ It has usually been assumed that there is a sharp split of authority on this question. The majority rule places the risk upon the purchaser because, under the doctrine of equitable conversion, he is the equitable owner of the property; consequently, the vendor may enforce the contract; the purchaser may not rescind, he may not compel a reduction in the purchaseprice; nor may he take legal title and then recover damages for the deterioration of the property in the interval between contract and deed. ${ }^{7}$

* Member of the Illinois bar.

I See Levinkind, Risk of Loss and Benefit of Insurance in Executory Contracts for the Sale of Real Property, Second Annual Report of the Law Revision Commission of the State of New York 763 (I936).

'See Williston, The Risk of Loss after an Executory Contract of Sale in the Common Law, 9 Harv. L. Rev. 106 (I895); 2 Williston, Contracts $\$ \$ 927-53$ (I920).

3 Approved by the National Conference of Commissioners on Uniform State Laws, July, I935.

4 See Second Annual Report of Law Revision Commission of the State of New York 775, 1026 (1936). Adopted without changes in South Dakota. See S.D.L., I937, c. 258, p. 362.

5 See note 46 infra. $\quad{ }^{6}$ See note 48 infra for discussion of forms used in practice.

7 For early recognition of this rule, see Peere Williams' acceptance of the erroneous report of Cass v. Rudele, 2 Vern. 280 (1692), in his note to White v. Nutt, I Will. P. 6I (I 702); Poole v. Shergold, 2 Brown Ch. R. II8 ( 1786 ), also reported in I Cox 273; 2 Powell, Contracts 6r 
This view emphasizes the security of contract. ${ }^{8}$ The minority rule places the risk upon the vendor because the loss makes impossible the fulfilment of an implied condition that the property should remain unimpaired until the transfer of legal title; where the loss is not substantial, it is true, the purchaser may only enforce an abatement, he may not rescind; 9 but where the loss is substantial, the contractual relation is at an end. ${ }^{x 0}$ The vendor may not recover damages for the purchaser's refusal to go on with the contract, nor may he enforce specific performance; on the other hand, neither may the purchaser recover damages for the vendor's inability to convey the property as it was at the date of the contract ${ }^{\text {II }}$ nor enforce specific performance with abatement, but he may do what he usually wants to do, recover any deposit that he has made. This view emphasizes the uncontemplated change of circumstances. ${ }^{12}$

The existence of so sharply defined majority and minority rules, however, may well be doubted. Some two hundred risk of loss cases have by this time been accumulated, and it appears, upon analysis, that the facts of these cases are sufficiently different so that the decisions illustrate, not two conflicting rules, but one general rule with an exception. The majority rule, placing the loss upon the purchaser, becomes, in these terms, the general rule, while the minority rule, placing the loss upon the vendor, is reduced to the rank of an exception.

The exceptional situation is this: before much time has elapsed since the agreement and, consequently, before performance has proceeded very far, the property suddenly suffers a serious deterioration in value. The consideration fails, not necessarily before any performance at all, but before the object of the parties and actual security in the relation have been substantially achieved. The purchaser has paid but little; usually he

(1790); Sugden, Vendors and Purchasers 185 ( 3 d ed. 1808); Durrett v. Simpson's Representatives, 3 T. B. Mon. (Ky.) 5I7, 52 I (I826); Oldham v. Kennedy, 3 Humph. (Tenn.) 260 (I842).

${ }^{8}$ Sir Lloyd (later Lord) Kenyon, in Poole v. Shergold, 2 Brown Ch. R. ri8, II9 (I786): "The difference arising from the calamities of the times, ought not to rescind the contract." See also Ranck v. Wickwire, 255 Mo. 42, 6r, I64 S.W. 460 (I9r3), and the dissent of Bridges, J., in Ashford v. Reese, I32 Wash. 649, 666, 233 Pac. 29, 38 (I925).

9 Bautz v. Kuhworth, I Mont. I33 (I869); Boehm v. Platt, II5 Misc. 55, I89 N.Y.S. I6 (Ig2r).

10 This position originated in this country with Thompson v. Gould, zo Pick. (Mass.) I34 (1838). For a similar attitude in English cases, see Stent v. Bailis, 2 Will. P. 217 (r724); Pope v. Roots, I Brown P.C. 370 (I774).

Ix But see Martin Grocery Co. v. E. Meng Co., 2I2 Ky. 469, 279 S.W. 66I (I926).

${ }^{12}$ See the early English cases ciled in note to supra and Connell v. Savings Bank of Newport, 47 R.I. 60, 63, I29 Atl. 803, 805 (I925). 
has not taken possession or otherwise begun the beneficial enjoyment of his purchase; whether or not the purchaser should have taken out insurance in so short a time, the vendor is the one who has whatever insurance there may be; and in general neither party has made any serious change of position in reliance upon the contract. Hence, when the question is raised whether a relation, so drastically altered in its early stage, must still be maintained or whether it may not better be broken off, the courts choose the latter alternative. ${ }^{{ }^{3}}$

In contrast to this exceptional situation, cases in which the purchaser is held to his contract reveal transactions in which performance has advanced more toward completion, as where the purchaser has collected rent or gone into possession and perhaps even made improvements, taken out insurance, started paying taxes, and paid more toward the purchaseprice than mere earnest money; moreover, the loss may not even be substantial. In short, the factors indicating security of contract as an established fact relied upon by the parties are here present. If the policy of security of sale transactions has any vitality at all, it should operate here. Disruption of the transaction-restoration of a fictional status quo-is out of the question. ${ }^{13 \mathrm{~s}}$

${ }_{3}$ The only cases contra seem to be Brewer v. Herbert, 30 Md. zor (1869) (rescission refused, vendor granted specific performance), and The Oak Building \& Roofing Co. v. Susor, 32 Ohio App. 66 (rg29) (rescission refused). Libman v. Levenson, 236 Mass. 22I, r28 N.E. I3 (I920). See also Cooper v. Huntington, r78 Cal. I6o, I72 Pac. 59r (rgr8); Anderson v. Yaworski, I20 Conn. 390, I8I Atl. 205 (x935); Wheeler v. Gahan, $206 \mathrm{Ky} .366,267$ S.W. 227 (r924); Page v. Loeffler, r46 La. 890, 84 So. r94 (r920); Wells v. Calnan, I07 Mass. 5 I4 (r87r); Hawkes v. Kehoe, I93 Mass. 4I9, 79 N.E. 766 (I907); Wicks v. Bowman, 5 Daly (N.Y.) 225 (I874); Listman v. Hickey, 65 Hun 8, I9 N.Y.S. 880 (I892), aff'd without opinion, I43 N.Y. 630,37 N.E. 827 (1894); Connell v. Savings Bank of Newport, 47 R.I. 60, I29 Atl. 803 (I925); Bowdle v. Jencks, I8 S.D. 80,99 N.W. 98 (I904). Four cases may be added, in which a defect in the vendor's title might have been the ground of decision, but was not made much of in the opinion: Conlin v. Osborn, r6x Cal. 659, r2o Pac. 755 (I9Ir); Elmore v. StephensRussell Co., 88 Ore. 509, x71 Pac. 763 (r9r8); Good v. Jarrard, 93 S.C. 229, 76 S.E. 698 (I9I2); Northern Texas Realty \& Construction Co. v. Lary, I36 S.W. 843 (Tex. Civ. App. I9II).

${ }^{{ }^{32}}$ Johnston v. Jones, I2 T. B. Mon. (Ky.) 326 (I85I) and McGinley v. Forrest, I07 Neb. 3 Io, 186 N.W. 74 (I921), are typical cases. See also Poole v. Shergold, 2 Brown Ch. R. II8 (I786); Owen v. Pomona Land \& Water Co., x3r Cal. 530, 63 Pac. 850 (rgor); Kelly v. Smith, 218 Cal. 543, 24 P. (2d) 47 (1933); O’Brien v. Paulsen, x92 Iowa I35I, I86 N.W. 440 (I922); Linn County Bank v. Grisham, ro5 Kan. 460, r85 Pac. 54 (I9r9); Martin v. Carver's Adm'r, 8 Ky. 56, x S.W. r99 (r886); Walker v. Owen, 79 Mo. 563 (I883); Marion v. Wolcott, 68 N.J. Eq. 20, 59 Atl. 242 (I904); Mott v. Coddington, I Abb. Pr. (N.S.) (N.Y.) 290 (r863); Sewell v. Underhill, I97 N.Y. r68, 90 N.E. 430 (rgro); Sutton v. Davis, I43 N.C. 474, 55 S.E. 844 (Ig06); The Farmers Tobacco Warehouse Co. v. Eastern Carolina Warehouse Corporation, 185 N.C. 518 , Ir7 S.E. 625 (r923); Woodward v. McCollum, I6 N.D. 42, IIr N.W. 623 (I907); Dunn v. Yakish, Io Okla. 388, 6r Pac. 926 (I900); Morgan v. Scott, 26 Pa. 5 I (r856); Maudru v. Humphreys, 83 W.Va. 307, 98 S.E. 259 (I9I9); Neponsit Realty Co. v. Judge, 
There are, it is true, a few cases releasing the purchaser in situations that would seem to call for the application of the general rule. ${ }^{\mathrm{I}}$ All of them involve the question whether a conditional or installment sale should be disrupted after a fire loss, when the purchaser has been in possession some considerable time and has made improvements and paid taxes and a substantial part of the purchase-price. In a recent California decision $^{\text {TS }}$ the court viewed the purchaser in such a case as essentially a grantee in possession under a purchase-money mortgage and consequently put the loss on him. In the light of this decision, the unsoundness of these cases is clear. ${ }^{16}$

Support for such a reconciliation of the so-called majority and minority cases may be found, first in the fact that courts in certain states have placed the loss now upon the vendor and now upon the purchaser, using in the one case the implied-condition rationale of the minority rule and in the other the equitable conversion rationale of the majority rule. ${ }^{x 7}$ Have these courts been lurching from one general rule to the other like Luther's drunken rider, or do their decisions illustrate a general rule with an exception? The latter alternative seems correct, for in practically all the states the loss is placed upon the vendor comparatively infrequently and only in exceptional cases, and, as we have seen, the typical situation of these

I06 Misc. 445, I76 N.Y.S. I33 (I9rg); Persico v. Guernsey, I29 Misc. I9o, 220 N.Y.S. 689 (I927). Paine v. Meller, 6 Ves. Jr. 349 (I8or), historically the leading general-rule case, should be considered in relation to the foregoing cases, especially Sewell v. Underhill, also in relation to the fault cases listed note 50 infra, especially Ranck v. Wickwire.

${ }_{4}$ Lubarsky v. Chavis, 99 Cal. App. 6ro, 279 Pac. 205 (I929); Gould v. Murch, 70 Me. 288 (I879); Durham v. McCready, 29 Me. 279, 15I Atl. 544 (1930); Szatkus v. Schaub, I4I Misc. $x 77,252$ N.Y.S. 350 (I93 r); Powell v. Dayton, etc. R. R. Co., I2 Ore. 488,8 Pac. 544 (1885) (dictum); Ashford v. Reese, $x_{32}$ Wash. 649, 233 Pac. 29 (I925).

Is Kelly v. Smith, 218 Cal. 543, 24 P. (2d) 47 I (1933).

${ }^{26}$ Lubarsky v. Chavis, 99 Cal. App. 6Io, 279 Pac. 205 (rg29) overruled by Kelly v. Smith, id. Ashford v. Reese, I32 Wash. 649, 233 Pac. 29 (I925) has been weakened, see Lantz, Rights of Vendees under Executory Contracts of Sale, 3 Wash. L. Rev. I (I928); subsequent Washington decisions, while following the case, have restricted rescission to cases of substantial loss, so that the most either party can get, in the absence of that factor, is specific performance with abatement. Cameron v. Hurn, I47 Wash. 434, 266 Pac. I79 (I928); Capital Savings \& Loan Ass'n v. Convey, I75 Wash. 224, 27 P. (2d) I36 (r933). See also Morgan v. Hymer, I8 Ky. 639, 37 S.W. 576 (I896), which, in allowing an abatement, would seem to be contra to such Kentucky decisions as Johnston v. Jones, I2 T. B. Mon. (Ky.) 326 (185I), and Martin v. Carver's Adm'r, $8 \mathrm{Ky} .56$, r S.W. rg9 (r886).

17 See the California, Kentucky, and New York cases cited in notes I2 and I3a supra; see also the New Jersey cases, Hartman v. Church Construction Co., Ior N.J. Eq. 512, I39 Atl. 484 (r927), and Marion v. Wolcott, 68 N.J. Eq. 20, 59 Atl. 242 (r904), and the Oregon cases, Elmore v. Stephens-Russell Co., 88 Ore. 509, I 7 r Pac. 763 (rgr8), and Hill v. Doerfier, r5o Ore. 628,47 P. (2d) 260 (I935). 
exceptional cases is fairly distinguishable from those cases where the loss is placed upon the purchaser. The courts that have seemingly followed both majority and minority rules are peculiar merely in having had to consider both general-rule and exceptional situations, while most courts have had only the one or the other.

Further support for the suggested reconciliation is found in the analogy of the law on risk of loss in sales of goods. Here the general rule is that the goods are at the buyer's risk after the agreement is made ${ }^{18}$ but there are exceptional cases where the courts will imply a condition that the goods were to remain in existence, substantially unimpaired, for some length of time after the agreement. ${ }^{19}$ The rationale of these cases corresponds to that used in the land cases. When the courts place the loss upon the buyer of goods or the purchaser of land, they call him the owner, legal in the goods cases and equitable in the land cases; when they place the loss upon the seller or the vendor, they conjure up an implied condition. If loss on the buyer and the accompanying ownership rationale is usual in the goods cases, while loss on the seller and the implied-condition rationale is exceptional, why not also in the land cases? It would seem that security of contract should be insisted upon as a general rule in all selling transactions, whether the subject-matter is land or goods. ${ }^{20}$

The cases so far discussed have all involved contracts between private persons and subject-matters impaired by some natural cause, such as fire, flood, windstorm, or collapse. Judicial sales and condemnation cases have been reserved for separate treatment at this point because their facts are different from the ordinary risk of loss cases just considered and the courts do not, therefore, handle them in quite the same way.

Judicial Sales. After confirmation and before a deed has been delivered the purchaser may well be compared to a purchaser under a private contract. ${ }^{2 I}$ But between sale and confirmation his position is, formally at least, not the same, for while he is bound the official vendor is not. Since the purchaser has no assurance that the property will be his

${ }^{8}$ Unless the parties intend otherwise. See Uniform Sales Act $\$ \S 22, I 8, \mathrm{Ig}(\mathrm{r})$.

s9 Uniform Sales Act § 8; Agri Manufacturing Co. v. Atlantic Fertilizing Co., I29 Md. 42, 98 Atl. 365 (I916); Dexter v. Norton, 47 N.Y. 62 (I87I).

${ }^{30}$ Powell lays down the rule as affecting sales of land and goods both, without distinction. 2 Powell, Contracts 6I-76 (I790). See also Tufts v. Wynne, 45 Mo. App. 42 (I8gr), a goods case decided on the authority of Snyder v. Murdock, 5 I Mo. 175 (1872), and Walker v. Owen, 79 Mo. $56_{3}$ ( 1883 ), land cases. The courts often expressly say that the rule for land and goods should be and is the same, though they may differ in the formulation of the rule. Compare Thompson v. Gould, 20 Pick. (Mass.) 134 (1838), with Brewer v. Herbert, 30 Md. 301 (I869).

${ }^{2 \pi}$ See Robertson v. Skelton, I2 Beav. 260 (I849); Gates v. Smith, 4 Edw. Ch. (N.Y.) 702 (I846); McCarty v. Wilson, I84 Cal. 194, I93 Pac. 578 (1920). 
until the court has acted it would seem that he should not have the risk of loss placed upon him in the uncertain interval. ${ }^{22}$ Nevertheless, some American courts, carrying out a policy in favor of the stability of judicial sales, have held, where the confirmation would be a mere formality, that the risk of loss is on the purchaser from the time of the sale..$^{23}$

Condemnation Cases. A new factor appears in the condemnation cases, where the practical effect of the condemnation may be just the same as if the whole physical subject-matter, land and buildings both, had sunk into the sea. The vendor is always more favorably situated, for the award would exactly compensate him for the loss of his bargain, while the purchaser would only be approximately compensated for the loss of the specific land in which he was interested. This consideration may have had some influence on the decisions, for there is a noticeable favoring of the purchaser in condemnation cases. The criterion seems to be whether the purchaser's condition is so much altered for the worse, as compared to the vendor's, that he should not be held to his contract. It is, therefore, very important how much of the property is condemned, what is condemned, and how adequate the award is likely to be, if there is one and if the purchaser gets it. Where the condemnation deprives the purchaser of all use and possession of the property, so that the vendor can convey at most only an underlying fee, the vendor is not allowed to enforce the contract, and the purchaser may rescind. ${ }^{24}$ The purchaser may, but need not, accept the award and go on with the contract.25 And this result is reached whether condemnation occurs before or after the purchaser is in possession. ${ }^{26}$ But where the part taken is not a material part of the premises and an adequate award is paid to the purchaser, he may not

22 Ex parte Minor, Ir Ves. Jr. 559 ( 1805 ); Stephenson v. Bain, 8 Ont. Pr. Rep. I66, 258 (I880); Harrigan v. Golden, 4I App. Div. 423, $5^{8}$ N.Y.S. 726 (I899); In re Sermons' Land, I82 N.C. I22, 108 S.E. 497 (x921); Eakin \& Co. v. Herbert, 4 Coldw. (Tenn.) II6 (I867). Because the loss was trifling, the purchaser was denied rescission, unless the vendor refused to repair or offered compensation, in Aspinwall v. Balch, 4 Abb.N.C. (N.Y.) I93 (1877).

23 Thomas v. Caldwell Admir., I36 Ala. 518, 34 So. 949 (I902); Miles v. Wilson, 3 Harr. (Del.) 382 (184I); Vance's Adm'r v. Foster, 9 Bush (Ky.) 389 (I872); Cropper v. Brown, 76 N.J.Eq. 406, 74 Atl. 987 (I909); Robb v. Mann, II Pa. St. 300 (1849). But see the situation in Demmy's Appeal, 43 Pa. I55 (1862).

24 Funt v. Inner Harbor Land Co., 6I Cal. App. 27x, 214 Pac. 998 (I923); Ogren v. Inner Harbor Land Co., 83 Cal. App. I97, 256 Pac. 607 (I927); Ford v. Russell, I 3 La. App. 390, I 28 So. 3 Io (I930); Kares v. Covell, I80 Mass. 206, 62 N.E. 244 (I902); Hartman v. Church Cons. Co., ror N.J.Eq. 512, I39 Atl. 484 (I927); Schaefer v. E. F. Gregory Co., II2 Wash. 408, I92 Pac. 968 (I920). See also Haiss v. Schmukler, I2I Misc. 574, 201 N.Y.S. 332 (1923); Stent v. Bailis, 2 Will. P. 2 I7 ( 7724$)$. Contra, Clarke v. Long Island Realty Co., I26 App. Div. 282, I10 N.Y.S. 697 (1908).

${ }^{25}$ See the Hunt and the Ogren cases and the dissent in the Clarke case, note 24 supra. But see Schaefer v. E. F. Gregory Co., note 24 supra.

${ }^{26}$ In the Hariman case, Ford v. Russell, and Haiss v. Schmukle-before possession; in the Hunt case, the Ogren case, and the Schaefer case-after possession. See note 24 supra. 
rescind or collect damages, and the vendor may insist upon the contract. ${ }^{27}$ $A$ fortiori, where possession is not affected at all, but the purchaser is merely denied a certain use of the property, he may not rescind, and the vendor may enforce specific performance. ${ }^{28}$

The question remains to be considered whether the present law on risk of loss should be superseded by a rule making possession the sole criterion - such a rule, for instance, as is embodied in the proposed Uniform Vendor and Purchaser Risk Act. The material part of the Act reads as follows:

SECTION 1. (Risk of Loss.) Any contract hereafter made in this State for the purchase and sale of realty shall be interpreted as including an agreement that the parties shall have the following rights and duties, unless the contract expressly provides otherwise:

(a) If, when neither the legal title nor the possession of the subject matter of the contract has been transferred, all or a material part thereof is destroyed without fault of the purchaser or is taken by eminent domain, the vendor cannot enforce the contract, and the purchaser is entitled to recover any portion of the price that he has paid;

(b) If, when either the legal title or the possession of the subject matter has been transferred, all or any part thereof is destroyed without fault of the vendor or is taken by eminent domain, the purchaser is not thereby relieved from a duty to pay the price, nor is he entitled to recover any portion thereof that he has paid.

The Act obviously does not state the present law on risk of loss in land sales, for it is apparent from the cases that possession has not hitherto been the sole controlling factor. In the typical exceptional or impliedcondition situation, the fact that the purchaser has not taken possession or otherwise begun the beneficial enjoyment of his purchase may be one of the more obvious reasons why he should not be held, if it indicates that the transaction has not achieved much actual security. A few opinions attach much significance to possession; $; 2$ others simply mention the purchaser's lack of possession in describing the situation as a whole; ${ }^{30}$ still others, in typical implied-condition cases, have not even mentioned what significance, if any, was given to possession; ${ }^{3 x}$ and in some cases the

${ }^{27}$ Stevenson v. Loehr, 57 Ill. 509 (I87I); Kuhn v. Freeman, I5 Kan. 423 (1875); Reife v. Osmers, 252 N.Y. 320 , 169 N.E. 399 (r929); Hill v. Doerfler, I50 Ore. 628, 47 P. (2d) 260 (I935).

${ }^{28}$ Summers v. Midland Co., I67 Minn. 453, 209 N.W. 323 (I926); Oldham v. Kennedy, 3 Humph. (Tenn.) 260 (I842).

${ }^{29}$ Wicks v. Bowman and Good v. Jarrard, 93 S.C. 229 , 76 S.E. 689 (19I2).

${ }^{30}$ Coulin v. Osborn, I6I Cal. 659, I20 Pac. 755 (I9II); Wells v. Calnan, I07 Mass. 5I4 (187x); Cownell v. Savings Bank, 47 R.I. 60, I29 Atl. 803 (r925).

${ }^{3}$ Anderson v. Yaworski, I20 Conn. 390, I8I Atl. 205 (I935) (the dissent şaid possession was not controlling); Page v. Loeffler, I46 La. 890, 84 So. I94 (I920); Hawkes v. Kehoe, I93 -Mass. 4I9, 79 N.E. 766 (I907); Libman y. Levenson, 236 Mass. 22I, I28 N.E. I3 (I920); Listman v. Hickey, 65 Hun 8, Ig N.Y.S. 880 (1892). 
purchaser has been in possession, yet the conclusion of the court was that the contractual relation should be broken off..$^{32}$ In typical general-rule situations, the fact that the purchaser has taken possession or otherwise enjoyed his purchase for some time after the agreement may be one reason for concluding that the transaction has achieved an actual security that should not be disturbed; it would seem to have had that influence in a good many of the cases. But possession in the purchaser as the sole reason for holding him to his bargain is an unduly simple and narrow interpretation of many decisions, ${ }^{33}$ and the purchaser does not have to be in possession to enable the court to conclude that "the difference arising from the calamities of the times, ought not to rescind the contract." 34 In judicial sales, possession seems to have had little significance; ${ }^{35}$ in the condemnation cases, other factors have been controlling. ${ }^{36}$

Not only does the Act propose to change the present law on risk of loss in land sales, it also would make it different from the law in sales of goods. Symmetry and the historical development of the same general rule in each field suggest that there should be no difference. ${ }^{37}$ It is in practice, not in theory, that the courts should take account of the real differences between land and goods transactions. They might be slower to hold a purchaser, because for several reasons land transactions are apt to be slower in achieving an actually secure and settled character; hence the occurrence of the implied-condition exception might be more frequent in land cases. It is true that in conditional sales of goods the favored rule is that the risk of loss is on the party in possession. ${ }^{38}$ But why treat all land sales as if they were conditional or installment sales? As a matter of fact, the courts have not regarded conditional sales of land as having anything peculiar about them that would take them out of the operation of the

${ }^{32}$ Cooper v. Huntington, $178 \mathrm{Cal}$. I60, I72 Pac. 59I (rgr8); Wheeler v. Gahan, $206 \mathrm{Ky}$. 368,267 S.W. 227 (Ig24); Good v. Jarrard, 93 S.C. 629,76 S.E. 689 (I9I2).

${ }_{33}$ Such as Kelly v. Smith, 218 Cal. 543, 24 P. (2d) 47 I (r935); Johnston v. Jones, I2 T. B. Mon. (Ky.) 326 (185I); Marion v. Wolcott, 68 N.J.Eq. 20, 59 Atl. 242 (I904); Sewell v. Underhill, r97 N.Y. 168, 90 N.E. 430 (I9I0); Sutton v. Davis, I43 N.C. 474 , 55 S.E. 844 (Ig06); The Farmers' Tobacco Co. v. Warehouse Corp., 185 N.C. 518, Ir7 S.E. 625 (I923).

34 Poole v. Shergold, 2 Brown Ch. R. II8 (I786); O'Brien v. Paulsen, I92 Iowa I35I, I86 N.W. 440 (I922); Martin v. Carver's Adm'r., 8 Ky. 56, I S.W. I99 (I886); McGinley v. Forrest, I07 Neb. 3 10, 186 N.W. 74 (I92I); Woodward v. McCollum, I6 N.D. 42, III N.W.. 623 (Ig02); Maudru v. Humphreys, 83 W.Va. 307, 98 S.I. 259 (IgIg); see also Cammarata v. Merkewitz, I20 Misc. 503 , I98 N.Y.S. 825 (1923).

35 See page 264 supra.

${ }^{36}$ See page 265 supra.

3i It may be somewhat puzzling in this connection to remember that Mr. Williston also drafted the Uniform Sales Act.

$3^{8}$ Uniform Conditional Sales Act $\S 27$. 
general rule and its exception, and no special rule has been developed that the purchaser may escape the loss if he has not taken possession.

The probable consequences of the Act are even more to be criticized than its content. Its passage, far from settling the risk of loss question, may well cause considerable sections of the law on the subject to be relitigated for years to come, until the implications of the possession test are definitely explored. And because the Act sets up a new rule, in statutory form, this litigation is altogether likely to degenerate into conceptual disputes over the meaning of its terms. Of these disputes, the term "possession" is only one probable source, as the following questions show. Answers to some of them, it is true, might be furnished by a revision of the Act. ${ }^{39}$

Does the Act, purporting to apply to "any contract," apply alike to agreements between private persons and judicial sales? $4^{\circ}$ Would the courts, under the Act, be more ready or less ready to find that a binding agreement had been entered into than they have been in some cases? ${ }^{4 x}$ What effect would the Act have where the agreement was entered into in ignorance of condemnation proceedings already begun? ? $^{42}$ What effect would it have on agreements unenforceable at the time of the loss because of the Statute of Frauds? ${ }^{43}$ Especially, what effect would the Act have on the situations where there is a defect in the vendor's title at the time of the loss? ${ }^{44}$ The courts hitherto have been notably indulgent to the purchaser

39 For the changes and additions made by the New York legislature, in adopting the Act, see Second Annual Report of the Law Revision Commission of the State of New York 755, I027, 1042 (I936).

$4^{\circ}$ See page 264 supra.

4 White v. Wansey, II6 Fed. 345 (C.C.A. 6th I902); Skeen v. Ellis, ro5 Ark. 5I3, I52 S.W. ${ }_{53}$ (1912); Lombard v. Chicago Sinai Congregation, 64 Ill. 477 (I872).

42 Cavenaugh v. McLaughlin, 38 Minn. 83, 35 N.W. 576 (I887); Goldstein v. Ehrlick, 96 N.J.Eq. 52, 124 Atl. 761 (I924); Johnston v. Callery, I73 Pa. I29, 33 Atl. I036 (1896), I84 Pa. I46, 39 Atl. 73 (I898); Miller v. Calvin Philips \& Co., 44 Wash. 226, 87 Pac. 264 (Igo6); but see Nixon v. Marr, I9o Fed. 9I3 (C.C.A. 8th I9II), and Rifkin v. Ed Zit Holding Corp., 254 N.Y. 352 , I 73 N.E. 219 (I930).

43 Higbie v. Shields, 27 Cal. App. 536, I50 Pac. 80r (I9r 5); Burks v. Douglass, $156 \mathrm{Ky}$. 462, r6I S.W. 225 (I9I3); Thompson v. Gould, 20 Pick. (Mass.) I34 (1838); Dickinson v. Wright, 56 Mich. 42, 22 N.W. 3I2 (1885); Blew v. McClelland, 29 Mo. 304 (I860); but see Walker v. Owen, 79 Mo. 563 (1883), and Collier v. Coates, I7 Barb. (N.Y.) 47 (I854).

44 Mackey v. Bowles, 98 Ga. 730, 25 S.E. 834 (1896); Phinizy v. Guernsey, III Ga. 346, 36 S.E. 796 (I900); Calhoon v. Belden, 3 Bush (Ky.) 674 (I868); Frankiewicz v. Konwinski, 246 Mich. 473, 224 N.W. 368 (I929); Kinney v. Hickox, 24 Neb. I67, 38 N.W. 816 (1888); Smith v. McCluskey, 45 Barb. (N.Y.) 6Io (I866); Bechtel v. Dakota National Bank, 35 S.D. I9I, I5I N.W. 887 ( 19 r7); Amundson v. Severson, 4r S.D. 377, I70 N.W. 633 (xgrg); Hendricks v. Gillespie, 25 Gratt. (Va.) I8I (I874). But see Poole v. Shergold, 2 Brown Ch. R. rI8 (I786); Felt v. Morse, 80 Fla. I54, 85 So. 656 (I920); Persico v. Guernsey, I29 Misc. r9o, 220 N.Y.S. 689 (I927). 
in such cases. Suppose he is in possession when the loss occurs and the vendor is in no default in not then having a perfect title. If the vendor presents an acceptable title at the appointed time, may the purchaser decline it, under the Act, as he may do now, according to the cases?45

The phrases "without fault of the purchaser" and "without fault of the vendor" would have what effect in cases involving negligence or laches or other inequitable conduct by one of the parties? ${ }^{46}$ Will the clause "unless the contract expressly provides otherwise" require a reconsideration of the not uncommon and somewhat ambiguous provision that the vendor shall deliver the premises in the same condition as at the date of the contract, usual wear and tear excepted? Some courts have held that this is not a risk of loss clause at all, ${ }^{47}$ others have found it an express assumption of risk by the vendor. ${ }^{48}$

45 See Calhoon v. Belden, Kinney v. Hickox, Bechtel v. Dakota National Bank, note 44 supra; but see Felt v. Morse and Persico v. Guernsey, note 48 supra.

${ }^{4} 6$ For cases attributing the loss to the fault of one of the parties, see Royal Bristol Permanent Building Society v. Bomash, L.R. 35 Ch. D. 390 (1887); Durrett v. Simpson's Representatives, 3 T. B. Mon. ( $\mathrm{Ky}$.) 517 (1826); Cornish v. Strutton, 8 T. B. Mon. (Ky.) 586 $(1848)$. For the effect of negligence and delay combined, see Lynch v. Wright, 94 Fed. 703 (C.C.A. gth I899), with which compare Harford v. Purrier, I Madd. 532 (I8r6). And see Minchin v. Nance, 4 Beav. 332 (I84I); Styles v. Blume, I2 Misc. 421 , 33 N.Y.S. 620 (I895). See also Harford v. Purrier, I Madd. 532, 540 (I8I6); Eppstein v. Kuhn, 225 Ill. Ir5, 80 N.E. 80 (rgo7); Smith v. Cansler, 83 Ky. 367 (1885); Ranck v. Wickwire, 255 M. 42, I64 S.W. 460 (19r3). And see Wong Ah Sure v. Ty Fook, 37 Cal. App. 465, I74 Pac. 64 (rgr8); La Chance v. Brown, 4 I Cal. App. 500, I83 Pac. 216 (I9I9); Parcell v. Grosser, I09 Pa. 617, I Atl. 909 (I885), Barker v. Smith, 3 Sneed (Tenn.) 289 (I855). Compare Paine v. Meller, 6 Ves. Jr. 349 (I8oI), with Phinizy v. Guernsey, Bechtel v. Dakota National Bank, Amundson v. Severson, note 44 supra.

47 Hawkes v. Kehoe, 193 Mass. 419, 79 N.E. 766 (1907); and see Block v. Citizens Trust \& Savings Bank, 57 Cal. App. 518, 207 Pac. $5^{\text {to }}$ (1922).

${ }^{8}$ Rhomberg v. Zapf, 20 r Iowa 928, 208 N.W. 276 (1926); Combs v. Fisher, 3 Bibb (Ky.) 5I (r8r3); Green v. Kelly, 20 N.J.L. 544 (1845); Brownell v. Board of Education, 239 N.Y. 369 , r46 N.E. 630 (1925). See also Marks v. Tichenor, 85 Ky. 536, 4 S.W. 225 ( 1887 ); Kincheloe v. Smith, 28 Ky. 1329, 9r S.W. Ir45 (1906).

Standard forms in use in the city of New York provide that "the risk of loss or damage .... by fire until delivery of the deed is assumed by the seller." See Bergerman and Roth, New York Real Property Forms, Form no. 252, Form no. 253 (r93r). The "Chicago Real Estate Board Sales Contract" provides that if the loss to the improvements is less than $25 \%$ of the insurance, the purchaser shall be credited on the purchase-price with the amount of insurance money received by the vendor; if the loss is $25 \%$ or more, the purchaser must elect to take his credit or the contract is at an end; and if there is not insurance sufficient to cover the loss and the loss is $5 \%$ or more of the value of the improvements, the purchaser may recover his earnest money. Most printed forms, however, are silent on the subject. The New York and Chicago forms just noticed make no provision in anticipation of condemnation. The "Chicago Real Estate Board Exchange Contract" says nothing about risk of loss. See City of Marquette v. Michigan Iron \& Land Co., I32 Mich. I30, 92 N.W. 934 (I903); Pellegrino v. Giuliani, II8 Misc. 329, I93 N.Y.S. 258 (I922); Cameron v. Hurn, I47 Wash. 434, 
Does an exchange of properties come under "purchase and sale"?49

Are chickens "realty" under this Act? so $^{\circ}$ In general, what of the not infrequent cases where realty and personalty are sold as a unit?5x Do they come under the Act, does the personalty exempt them, or does the land come under the Act but not the goods? Suppose a defective deed has been delivered, has "legal title" been "transferred"? ${ }^{52}$ Would leaseholds be "realty," and if so, when would "legal title" be "transferred"?53 When a purchaser agrees to sell his interest to another, what is the "subjectmatter of the contract" and when is "legal title" "transferred" and by whom (if such a transaction comes under the Act at all)? ${ }^{54}$

What does the Act mean by "possession" and the transfer thereof? When the property is occupied by no one, who is in possession?55 Does "possession" include right to possession? ${ }^{56}$ If the purchaser has begun to collect rent has "possession" been "transferred"?57 How complete and unqualified does the "possession" (or right to possession, if that is sufficient) have to be ${ }^{38}$ When the purchaser is already in possession, before the contract, in some other relation to the vendor, has "possession" been "transferred"? s9

266 Pac. 179 (I928). Attempts to provide expressly for the risk of loss are likely to be too vague or, if explicit, not sufficiently comprehensive. See Polisiuk v. Mayers, 205 App. Div. 573, 200 N.Y.S. 97 (I923).

49 Was the transaction a "purchase and sale" in Hallett v. Parker, 68 N.H. 598, 39 Atl. 433 (I896); in Goldman v. Rosenberg, II6 N.Y. 78, 22 N.E. 259 (1889); in Fouts v. Foudray, 31 Okla. 221, r2o Pac. 960 (1912).

50 See Lubarsky v. Chavis, 99 Cal. App. 6ro, 279 Pac. 205 (r929).

${ }^{5 x}$ See Listman v. Kickey, 65 Hun. 8, ig N.Y.S. 880 (r892); Owen v. Pomona Land Co., I3 1 Cal. 530, 63 Pac. 850 (rgor); Johnston v. Jones, I2 T. B. Mon. (Ky.) 326 (x85x); Farmers Tobacco Warehouse Co. v. Eastern Carolina Warehouse Corp., x85 N.C. 518, II7 S.E. 625 (I923); Szatkus v. Schaub, I4I Misc. I77, 292 N.Y.S. 350 (I93I); Morgan v. Hymer, I8 Ky. 639,37 S.W. 576 (1896).

${ }^{2}$ See Wetzler v. Duffy, 78 Wis. I7o, 47 N.W. $x 84$ (r8go).

53 See Potts Drug Co. v. Benedict, I 56 Cal. 332, I04 Pac. 432 (I909); McKechnie v. Sterling, 48 Barb. (N.Y.) 330 (r867); Huguenin v. Courtenay, 2r S.C. 403 ( 1883 ).

54 See Thompson v. Norton, $\mathrm{I}_{4}$ Ind. I87 (I860); Gammon v. Blaisdell, 45 Kan. 221, 25 Pac. 580 (I89I).

55 See Wicks v. Bowman, 5 Daly (N.Y.) 255 (I874).

${ }^{56}$ See Dunn v. Yakish, ro Okla. 388, 6r Pac. 926 (r9oo); Ford v. Russell, 13 La.App. 360, I28 So. 3 ro (r930).

${ }^{57}$ See Linn County Bank v. Grisham, I05 Kan. 460 , 185 Pac. 54 (I9I8); Mandru v. Humphreys, 83 W.Va. 307 , 98 S.E. 259 (I9I9).

${ }^{58}$ See O'Brien v. Paulsen, I92 Iowa I35r, I86 N.W. 440 (I922); Johnston v. Jones, I2 T. B. Mon. (Ky.) 326 (I8gr); McGinley v. Forrest, ro7 Neb. 3 I0, r86 N.W. 74 (I92r); Dunn v. Yakish, ro Okla. 388, 6r Pac. 926 (rg00).

59 Cooper v. Huntington, I78 Cal. $x 60, x_{2}$ Pac. 59r (I918); Wheeler v. Gahan, $206 \mathrm{Ky}$. 366,267 S.W. 227 (r924); Good v. Jarrard, 93 S.C. 629, 76 S.E. 698 (19I2); Powell v. Dayton, I2 Ore. 488,8 Pac. 544 (I885) (dictum). 
What is "eminent domain"?60 When is the subject-matter "taken" by eminent domain?6x

Does the Act have any necessary application to the implied-condition exception? For that matter, is there any known means of preventing the courts' implying a condition that the property was to remain unaltered for some period of time after the contract? Any period of time will do, just so it is unexpired at the time of the loss. The courts are likely to imply such a condition, Act or no Act, if they find it necessary to release a purchaser who they think should be released. ${ }^{62}$

It is indeed doubtful whether the Act is worth the cost of the litigation it is likely to stir up. The risk of loss question would better be left as it is, in the hands of the courts and unconfined by any such verbal straitjacket as this proposed legislation. Such cases as arise in future will then benefit by free discussion of the only real question involved, Should the agreement be enforced? ${ }^{63}$ All factors, not merely possession, can then be taken into account, as they have been in the past; equitable considerations in favor of one of the parties, suggested by inequitable conduct on the other side, such as negligence of one kind or another, laches, temporizing, can be given effect; and the particular case can be considered in relation to the fundamental policy of security of contract. Such discussion and the decisions of the courts will be sufficiently guided by the cases already accumulated and the substantial uniformity already empirically achieved, under a better rule than the one proposed. The Act is undesirable, and indeed uniform legislation of any kind is, on this subject, unnecessary.

60 Haiss v. Schmukler, I21 Misc. 574, 20 I N.Y.S. 332 (I923); Summers v. Mudland Co., I67 Minn. 453, 209 N.W. 323 (I926); Oldham v. Kennedy, 3 Humph. (Tenn.) 260 (I842); Goldstein v. Ehlich, 96 N.J.Eq. 52, r24 Atl. 76I (r924).

6x See Hartman v. Church Construction Co., Ior N.J.Eq. 512, r39 Atl. 484 (I927); Nixon v. Marr, I9o Fed. Ir3 (C.C.A. 8th IgIr).

62 The Act assumes that if the purchaser has got only legal title it is perfectly proper to throw the loss upon him. This assumption is nothing new. See Cass v. Rudele, 2 Vern. 280 (I692); Marks v. Tichenor, 85 Ky. 536, 4 S.W. 225 (I887); Kincheloe v. Smith, 28 Ky. I329, 9I S.W. 445 (I906); Wetzler v. Duffy, 78 Wis. I70, 47 N.W. I84 (r89o); Gibson v. Eller, 13 Ind. I24 (1859); Wainscott v. Silvers, I3 Ind. 497 (1859). But why should a purchaser under a conditional sale contract who has not taken possession always avoid the loss, a grantee and purchase-money mortgagee never?

${ }^{63}$ This point is clearly recognized in cases where, after the contract, the property has greatly increased in value. See Cox v. Burgess, 96 S.W. 577 (Ky. Ig06); Low v. Treadwell, I2 Me. 44I (1835); Cady v. Gale, 5 W.Va. 547 (I87I); Hale v. Wilkinson, 2I Gratt. (Va.) 75 (187x). Here the courts do not fall into equitable conversion talk, but simply inquire whether there is any good reason against enforcing the agreement as it was made, just as risk of loss cases were discussed before it became fashionable to say that the loss should fall upon the "owner." See Poole v. Shergold and the dissent of Bridges, J., in Ashford v. Reese, r32 Wash. 649, 233 Pac. 29 (I929); note 7, Stent v. Bailis, 2 Will. P. 2 I (I 724); Pope v. Roots, I Brown P. C. 370 (r774). 